\title{
ВИСНОВОК ЕКСПЕРТА 3 ПИТАНЬ ПРАВА ЯК ДЖЕРЕЛО ОТРИМАННЯ АДВОКАТОМ ІНФОРМАЦІЇ ПРО ЗМІСТ НОРМ IHОЗЕМНОГО ПРАВА
}

ЩЕГЛАКОВ Іван Едуардович - студент міжнародно-правового факультету 1 курсу магістратури, 1 групи Національний юридичний університет імені Ярослава Мудрого

DOI 10.32782/LAW.UA.2021.4.24

\begin{abstract}
Е статті проаналізовано висновок експер та з питань права як один із способів отримання адвокатом інбормаиї про зміст норм іноземного права. Наголошено на тому, що хоча учасники справи не зобов'язані доводити суду зміст норм іноземного права, активна позииія адвоката в штому випадку сприяе якнайкращому захисту прав та інтересів клієнта та надає більше шансів отримати позитивне рішення.
\end{abstract}

Висновок експерта з питань права - новела изивільного процесуального законодавства, яка слугує, е тому иислі, джерелом інбормачій про зміст норм іноземного права. У статті було визначено, що використання наукових висновків широко використовується в судовому процесі Німеччини $i$ дозволяе суду дізнатися інформацію про іноземне законодавства.

Авторь наголошу.пт на тому, що правове регулювання інституту «правової експертизи» має низку недоліків. У статті проаналізовано думки науковиів та судову практику, які свідчать про те, що наразі існують такі проблеми? як неврегульованість порядку отримання висновку експерта з питань права, відсутність чітких критеріӥв до експерта з питань права, дискусійність критеріӥв, які ставляться до експерта, неврегульованість значення висновку експерта з питань права в иивільному процесі.

Автори пропонують внести зміни до чинного законодавства, які визначають, що висновок експерта з питань права може бути отриманий на замовлення учасника справи в науково-дослідних інститутах, університетах, інших науково-дослідних установах будь-якой борми власності. Також пропонується використовувати об'єктивні критерій (такі як індекс ицтувань, наявність наукових звань, відзнак та нагород) для визначення «визнаності» експерта з питань права. У статті запропоновано визначити в законі перелік випадків (неправильність висновку, суперечність висновку та невідповідність експерта критеріям), е яких суд має право не брати до уваги висновок експерта з питань права.

У статті наголошується на тому, що висновок експерта з питань права може бути ефективним інструментом для з'ясування норм іноземного права виключно після відповідних законодавчих змін.

Ключові слова: експертиза, експерт $з$ питань права, іноземне право, адвокат.

Постановка проблеми

Процеси глобалізації, розвиток іноземного співробітництва, міграція призводять до того, що іноземні суб'єкти (як фізичні, так і юридичні особи) стають учасниками правовідносин в Україні, що зумовлює розгляд в судах, зокрема, судах цивільної юрисдикції справ з іноземним елементом. У процесі розгляду таких справ нерідко виникає необхідність вивчення, з'ясування та аналізу змісту норм іноземного права.

У зв'язку з цим, адвокат як одна $з$ ключових фігур цивільного процесу задля доведення переконливості своєї позиції та ефективного представництва прав та інтересів 


\section{Цивільне, підприсмницьке, господарське та трудове право}

клієнта повинен з'ясовувати зміст іноземного права.

У процесі отримання інформації про зміст норм права інших держав адвокат може стикнутися з низкою проблем (складність перекладу, визначення компетентного органу, який може надати висновок щодо іноземного права, відсутність інформації у відкритих джерелах тощо), у зв’язку з чим законодавцем було впроваджено інститут експертизи 3 питань права, який, е тому числі, покликаний вирішити питання щодо 3'ясування судом та учасниками справи змісту норм іноземного права.

Водночас, цей правовий інститут не має достатнього правового регулювання, а практика його застосування є доволі суперечливою, у зв’язку з чим це питання потребує детального вивчення та аналізу.

\section{Аналіз останніх досліджень та публікацій}

Проблемні питання та способи отримання адвокатом інформації про зміст норм іноземного права були предметом дослідження таких вчених, як: Філіп'єв А. [1], Антонюк С., Заяць О., Скриньковський Р. [2], Погорецька Н. [5] та інші, наукові доробки яких $\epsilon$ важливим теоретичним підгрунтям для розуміння механізму отримання адвокатом у цивільному процесі відомостей про зміст правових норм інших держав.

Зокрема, Філіп'єв А.О. посилається на те, що, на відміну від англосаксонської системи, зміст норм іноземного права не входить до предмету доказування, адвокату для надання правової допомоги не проста можна, а необхідно займати активну позицію та самостійно з'ясовувати та доводити до відома суду інформацію про зміст норм іноземного права [1].

У своїх наукових працях Філіп'єв А. [1], Антонюк С., Заяць О., Скриньковський Р. [2] переважно виокремлюють такі способи отримання інформації про зміст норм іноземного права, як безпосереднє ознайомлення, афідевіт, отримання висновків від Міністерства юстиції України та Міністерства закордонних справ України. Погорецька Н. також наголошує на необхідності створення в Україні координаційного центру при Міністерстві юстиції, метою якого було б надання висновків про зміст іноземного законодавства.

У той же час, говорячи про способи отримання адвокатом інформації про зміст іноземного права, у науковій доктрині небагато уваги приділено такому новому інституту судового процесу як експертиза з питань права, яка також може бути дієвим способом отримання адвокатом інформації про зміст іноземного права.

\section{Формулювання цілей статті (постановка завдання)}

Визначення властивостей висновку експерта з питань права як джерела отримання адвокатом інформації про зміст норм іноземного права під час представництва клієнта в цивільному процесі, надання пропозицій щодо удосконалення правового регулювання інституту експертизи 3 питань права в цивільному процесі.

\section{Виклад основного матеріалу}

Чинне цивільне процесуальне законодавство не зобов'язує сторони та їх представників (адвокатів) надавати документи та інформацію щодо змісту норм іноземного права, залишаючи з'ясування цієї інформації прерогативою суду, оскільки відповідно до давньоримського принципу права «јura novit curia» (суд знає закони) саме суд обирає, які норми права слід застосовувати для вирішення конкретного спору. Мабуть, беззаперечним буде твердження, що саме суд як центральний суб'єкт цивільного процесу повинен знати правові норми та те, як їх застосовувати. Однак, у цьому контексті постає запитання: Чи повинен суд знати зміст законодавства іншої держави? Це питання, напевно, є риторичним з огляду на те, що правові відносини є настільки різноманітними, що неможливо передбачити всі можливі правові ситуації, як і неможливо вивчити законодавство всіх інших країн.

У зв'язку з цим, у справах, які потребують дослідження та встановлення змісту норм іноземного права, доречною б була допомога кожної зі сторін суду в отриманні інформації про іноземне законодавство, оскільки саме сторони, маючи матеріаль- 
но-правову та процесуальну зацікавленість, повинні прагнути як повного та всебічного встановлення обставин справи, так і правильного застосування правових норм до їх юридичного спору.

Закон України «Про міжнародне приватне право» у ч.3 ст.8 надає учасникам справи право подавати документи, що підтверджують зміст норм права іноземної держави, та сприяти суду в з'ясуванні такого змісту [3].

Філіп'єв А. О. $з$ приводу цього зазначає, що активна позиція сторін (а отже і адвокатів) у з'ясуванні дійсного змісту норм права іноземної держави є не просто бажаною, а й необхідною [1]. С.Коні зазначає, що проактивна поведінка - це пошук варіантів для поліпшення поточної ситуації та ефективніших способів вирішення таких ситуацій на майбутне [4]. Таким чином, саме активна позиція може сприяти якнайкращому та якнайшвидшому вирішенню спірної ситуації.

3 нашої точки зору, неможливо не погодитись 3 твердженням Філіп'єва А.О. з огляду на те, що проактивна позиція адвоката сприяє більш ефективному наданню правової допомоги, а отже, надає стороні більше шансів отримати позитивне рішення на ії користь.

Антонюк С., Заяць О., Скриньковський Р. зазначають про те, що залучення експертних висновків є одним зі способів отримання інформації про зміст іноземного права, основними перевагами якого є високий рівень достовірності, комплексність та системність [2].

Експертні висновки правових фахівців $\varepsilon$ доволі розповсюдженим способом з'ясування норм іноземного законодавства в правозастосовній практиці інших країн. Так, наприклад, у Німеччині суд у разі необхідності отримання інформації про зміст іноземного права може звернутися до професорів - спеціалістів 3 міжнародного приватного права та порівняльного правознавства, які працюють у спеціалізованих інститутах, а у випадку якщо експерт-учений не в змозі встановити зміст іноземного права, то суд Німеччини зобов'язаний призначити іноземного експерта [5].

У 2017 році і український законодавець вирішив передбачити можливість застосу- вання в цивільному процесі висновку експерта з питань права, а в 2018 році відповідні зміни набрали чинності.

На сьогодні час положення ч.1 ст.114 ЦПК України дозволяють учасникам справи подавати до суду висновок експерта у галузі права щодо змісту норм іноземного права згідно з їх офіційним або загальноприйнятим тлумаченням, практикою застосування і доктриною у відповідній іноземній державі [6].

Однак, нормативне регулювання цього інституту здійснено не на найвищому рівні, про що вже неодноразово наголошувалося науковцями.

Так, Бутирська I. наголошуе на тому, що законодавцем закладено суперечність у завданнях та правовому статусі експерта 3 питань права, який окреслений нечітко і 6 «недоврегульованим» [7]. Штефан А. також дійшла схожих висновків та зазначила, що ЦПК потребує вдосконалення в частині правового регулювання висновків експертів 3 питань права в цивільному процесі [8].

На нашу думку, основні проблеми, які виникають під час використання висновку експерта 3 питань права в процесі правозастосування в контексті отримання інформації про зміст норм іноземного права, можна виділити в три основні групи, які будуть висвітлені ниже:

1. Неврегульованість порядку отримання висновку експерта з питань права.

Положення ст. 114 ЦПК України передбачають, що висновок з питань права може бути поданий учасниками справи. Водночас, законодавство не містить будь-якого порядку отримання самим учасником справи (його адвокатом) такого висновку.

Для порівняння можна проаналізувати порядок призначення та проведення звичайної експертизи. Так, Закон України «Про судову експертизу» у ст. $7^{1}$ визначає декілька підстав для проведення судової експертизи, а саме наявність відповідного судового рішення, рішення органу досудового розслідування або договору з експертом чи експертною установою [9].

Таким чином, у разі необхідності проведення дослідження, яке потребує спеціальних знань, адвокат в інтересах клієнта 


\section{Цивільне, підприсмницьке, господарське та трудове право}

або від власного імені може укласти договір з експертом чи експертною установою для проведення експертизи.

Отже, при проведенні звичайної експертизи, адвокату необхідно укласти договір 3 відповідним експертом, який має необхідну освіту, кваліфікацію та сертифікат експерта. Експерт також попереджається про кримінальну відповідальність.

Коротка Н. О. зазначає про те, що Закон України «Про судову експертизу» не містить конкретизації вимог до особи експерта з питань права, які не визначає іiї жодний інший нормативно-правовий акт [10].

Вважаємо за доцільне не лише підтримати, а й доповнити думку Короткої Н.О. 3 приводу того, що Закон України «Про судову експертизу» не лише не визначає вимог до особи експерта з питань права, а взагалі не поширюється на правовідносини 3 приводу призначення та проведення так званої «правової експертизи». Наведене зумовлює ситуацію правового вакууму, за якої залишаються невирішеними питання порядку проведення експертизи з питань права та переліку установ, якими може проводитися така експертиза та на підставі яких документів.

Неможливим є також отримання висновку експерта 3 питань права шляхом направлення адвокатського запиту, оскільки Закон України «Про адвокатуру та адвокатську діяльність» забороняе використовувати адвокатський запит для надання консультацій і роз'яснень положень законодавства.

У зв'язку з цим, залишається незрозумілим, яким чином адвокат має залучити експерта з питань права та на якій підставі експерт повинен зробити висновок.

2. Відсутність чітких критерїв, яким повинен відповідати експерт з питань права.

У ст. 73 ЦПК України міститься положення про те, що експертом $з$ питань права може бути особа, яка має науковий ступінь та є визнаним фахівцем у галузі права.

Щодо критерію наявності наукового ступеня, то в цілому, в науковій спільноті склалася єдина думка щодо документів, які можуть його підтвердити. Озерський I. вказує на те, що наявність наукового ступеня повинна підтверджуватися відповідним дипломом кандидата наук, доктора філософії або доктора наук [11]. Майже аналогічної думки притримується і Старченко О., зазнаючи, що саме диплом про присвоєння наукового ступеня підтверджує те, що особа в установленому законом порядку захистила наукову роботу у формі публічного захисту [12].

Ми цілком погоджуємося з такими думками науковців, оскільки вони узгоджуються 3 приписами Закону України «Про вищу освіту», оскільки саме третій рівень вищої освіти (освітньо-науковий) передбачає наявність в особи відповідних знань та умінь, достатніх для вирішення комплексним проблем у галузі професійної діяльності та проведення власних наукових досліджень, результати яких можуть мати наукову цінність, а також бути корисними як для правової теорії, так i для правозастосування.

На жаль, критерій «визнаності як фахівця» не є таким же зрозумілим, як критерій «наявності наукового ступеня» і викликає дискусії в наукових колах.

Так, наприклад, Круковес В. зазначає: «Правова конструкція «визнаний фахівець у галузі права» є дискусійною, оскільки має оціночний характер, а тому на практиці виникнуть проблеми із пошуком таких «визнаних фахівців» у галузі права» [13]. Старченко О. вказує на те, що закнодавцем не передбачено чітких критеріїв встановлення рівня визнання експерта в галузі права [12]. Схожу думку також висловлюють також Кармаза О. та Кушерець Д. [14].

Про дискусійність категорії «визнаний фахівець» свідчить і судова практика.

Так, наприклад, Жовтневий районний суд м. Дніпропетровська в рішенні від 01.04.2021 p. в справі № 201/11390/17 зазначає: «Поняття «визнаний» 6 оціночним, а все що є оціночним на практиці призводить, як правило, до різночитання та плутанини» [15].

Окружний адміністративний суд м. Києва в рішенні від 15.03.2019р. в справі №826/14930/18 зазначив: «Що стосується питання «визнаності» ОСОБА_4 як фахівця у сфері правоохоронної діяльності, то законодавством не визначено критерії, наявність яких зумовлює віднесення особи до визнаних фахівців у цій сфері. За таких обставин суд приходить до висновку про те, що такі 
критерії не можуть бути абсолютними і залежать від багатьох чинників, у тому числі й від визнання тим чи іншим колом осіб» [16].

Таким чином, питання, кого саме слід вважати «визнаним фахівцем у галузі права» залишається без відповіді, що, у свою чергу, призводить до правової невизначеності. Адвокату для того, аби отримати висновок експерта з питань права, який стосується змісту норм іноземного права, необхідно визначити особу, яка буде зможе скласти такий висновок та відповідає необхідним законодавчим критеріям. Водночас, за відсутності єдиного підходу до розуміння критерію «визнаності» адвокат опиняється в ситуації, за якої він не має жодних гарантій, що залучений ним висновок експерта дійсно буде прийнятий судом як висновок визнаного правового фахівця.

Більше того, вищенаведена правова проблема призведе до того, що факт «визнаності» чи «невизнаності» фахівця фактично перейде до предмету доказування в справі, і адвокат, який долучає до матеріалів висновок експерта з питань права повинен буде доводити (без будь-яких об'єктивних критеріїв такого доведення) «визнаність» фахівця, що склав такий висновок.

Така ситуація лише буде ускладнювати процес з'ясування норм іноземного права i суперечить меті, задля якої було впроваджено інститут правової експертизи.

3. Неврегульованість значення висновку експерта з питань права в цивільному проueci.

Наразі чинний ЦПК України встановлює, що висновок експерта не є доказом, має допоміжне значення, а для суду не має обов'язкового характеру.

Фактично, такі положення ЦПК України створюють ситуацію правової невизначеності, за якої суд наділений занадто широкою дискрецією через відсутність будь-яких об'єктивних критеріїв для взяття до уваги чи відхилення висновку експерта в галузі права.

Це підтверджується і судовою практикою. Так, наприклад, Сєвєродонецький міський суд Ауганської області в рішенні від 25.07.2018p. в справі №428/5142/18 майже не навів ніяких обгрунтувань того, чому на- уково-правовий висновок не може бути взятий судом до уваги як висновок експерта в галузі права [17].

У Постанові від 30.10.2018p. у справі№ 826/6667/16 Верховний Суд зазначив, що врахування висновку експерта з питань права є правом, а не обов'язком суду [18].

Окрім того, законодавча конструкція щодо можливості врахування висновку експерта з питань права фактично сформульована таким чином, що суду значно простіше відмовити у залученні експерта 3 питань права, аніж обгрунтовувати необхідність врахування його висновку. Із ч.2 ст.115 ЦПК України випливає, що суд (у випадку якщо він посилається на висновок експерта 3 питань права) повинен його проаналізувати та зробити власні висновки. Водночас, для того, аби залишити висновок експерта з питань права поза увагою суду, достатньо лише послатися на те, що його врахування є правом суду, а не його обов'язком.

Таким чином, на сьогодні ЦПК України не містить жодних критеріїв, які б визначали, за яких умов висновок експерта з питань права, що відповідає вимогам закону, може братися судом до уваги, а за яких - ні.

Цією ситуацією правової невизначеності нівелюється сам інститут експертизи в галузі права, яка могла і повинна була бути ефективним способом з'ясування змісту норм іноземного права не лише учасниками справи, а й судом. Правові норми, які стосуються висновку експерта 3 питань права сконструйовані таким чином, що перед судом замість дослідження та з'ясування змісту іноземного права, окремим питанням буде поставати допустимість чи недопустимість висновку (який навіть не є доказом у справі).

У зв'язку з вищенаведеним, ми пропонуємо наступне вирішення правових проблем, пов'язаних 3 використанням висновку експерта з питань права в судовому процесі.

По-перше, законодавцю слід передбачити чітку процедуру отримання висновку експерта з питань права. У цьому контексті пропонується доповнити ч. 3 ст. 114 ЦПК України положеннями наступного змісту: «Висновок експерта 3 питань права може бути отриманий на замовлення учасника 


\section{Цивільне, підприємницьке, господарське та трудове право}

справи в науково-дослідних інститутах, університетах, інших науково-дослідних установах будь-якої форми власності. На висновок експерта з питань права поширюються вимоги, встановлені частинами 6-8 статті 102 ЦПК України».

По-друге, вкрай доцільним вбачається впровадження об'єктивних критеріїв до експерта $з$ питань права.

На нашу думку, у ЦПК України варто передбачити, що експерт з питань права може мати не будь-який науковий ступінь, а саме ступінь за відповідною правовою спеціалізацією (міжнародне приватне право, цивільне право тощо). Це зумовлюється тим, що особа, яка готує правовий висновок, повинна бути спеціалістом у відповідній галузі права, розуміти механізм правового регулювання та застосування відповідних норм, адже не може, наприклад, спеціаліст у кримінальному праві надавати висновок щодо того, як застосується торговельне право іншої країни.

Більше того, доопрацювання потребує і критерій «визнаності» фахівця в галузі права. У цьому контексті ми погоджуємося 3 думкою Шумило М., який зазначає, що в науковому світі експертом-науковцем може виступати тільки практикуючий, активний науковець, який щоденно кропіткою працею привносить у світ нові знання. Шумило М. також зазначає, що одним з критерієм визнаності експерта з питань права може виступати індекс Гірша, який вказує на частоту цитувань та посилань на відповідного науковця. Наразі індекс Гірша - це єдиний об'єктивний критерій, який може свідчити про визнаність експерта з питань права [19].

Схожу позицію висловив і Щербаковський М., який наголошує на тому, більш точним показником визначеності терміна «визнаний фахівець» 6 індекс цитування наукових робіт останнього, наприклад, h-index, Index Copernicus Value та інші індекси [20].

Доповнюючи та продовжуючи думку цих науковців, зауважимо, що для підтвердженням «визнаності» експерта 3 питань права можна також брати до уваги наявність у нього звання члена-кореспондента чи академіка відповідної академії наук, наявність звання «заслуженого професора», «заслуже- ного юриста» тощо, державних та інших нагород і відзнак.

По-третє, ми пропонуємо обмеження судової дискреції в питанні невзяття судом до уваги висновку експерта з питань права. У цьому контексті доречним би було також запровадження обов'язковості наведення суддею мотивів неприйняття висновку експерта $з$ питань права.

Ми пропонуємо доповнити ч.1 ст.115 ЦПК України реченням наступного змісту: «Суд може не брати до уваги висновок експерта у галузі права тільки у випадку невідповідності експерта у галузі права, критеріям, встановленим частиною 1 статті 73 ЦПК України, неправильності висновку або його суперечливості дійсному змісту норм іноземного права».

Лише за умови впровадження вищезазначених додаткових вимог та критеріїв як до самого експерта 3 питань права, так і до його висновку, висновок експерта з питань права може стати ефективним способом отримання адвокатом інформації про зміст норм іноземного права.

\section{Висновки та перспективи подальших досліджень у даному напрямку}

Висновок експерта з питань права є тим інструментом, який дозволяє як адвокату, так і суду з'ясовувати та досліджувати зміст норм іноземного права. На жаль, цей правовий інститут має низку прогалин і неточностей у його правовому регулюванні, які стосуються порядку отримання висновку експерта 3 питань права, критеріїв, що ставляться до самого експерта, та критеріїв оцінки висновку експерта з питань права судом.

Ці недоліки можуть бути усунуті шляхом впровадження більш чітких та конкретних вимог та критеріїв як до самого експерту 3 питань права, так і до суду, який повинен буде наводити чіткі мотиви відхилення висновку правової експертизи.

у такому випадку висновок експерта 3 питань права зможе стати ефективним способом отримання адвокатом інформації про зміст норм іноземного права під час представництва інтересів клієнта в цивільному процесі, і буде сприяти більш правильному, всебічному і повному вирішенню справи, 
яка потребує застосування права інших країн.

У перспективі також планується більш детально вивчити досвід зарубіжних країн щодо використання в їх судових системах правових висновків для з'ясування змісту іноземного права та на основі цього зробити відповідні пропозиції для України.

\section{Мiтература}

1. Філіп'єв А. О. Проблеми отримання адвокатом інформації про зміст норм іноземного права під час представництва інтересів клієнта в цивільному судочинстві. Часопис Національного університету "Острозька академія». Серія «Право». 2010. Вип. №1. с.1-8.

2. Антонюк С., Заяць О., Скриньковський Р. та ін. Проблеми отримання адвокатом правової інформації про зміст норм іноземного права під час представництва інтересів клієнта у цивільному судочинстві України. Traektoriâ Nauki = Path of Science. 2019. Vol. 5. No 10, c.5001-5010.

3. Про міжнародне приватне право. Закон України № 2709-IV від 23.06.2005. Дата оновлення: 06.10.2021. URL: https:// zakon.rada.gov.ua/laws/show/2709-15 (дата звернення: 03.12.2021).

4. "The 7 Habits of Highly Effective People» by Stephen R. Covey, Free Press, New York, 2004

5. Погорецька Н. В. Встановлення змісту норм іноземного права. Вісник Київсъкого начіонального університету імені Тараса Шевченка. Юридичні науки. 2012. Вип. № 93, с. 107-111

6. Цивільний процесуальний кодекс України від 18.03.2004 № 1618-IV . Дата оновлення: 05.08.2021. URL: https://zakon. rada.gov.ua/laws/show/1618-15 (дата звернення: 03.12.2021).

7. Бутирська I.A. Правовий статус експерта 3 питань права у господарському процесі. Науковий вісник Ужгородсъкого національного університету. 2018. Серія Право. Випуск 48. Том 1. С. 108-111.

8. Штефан А. Висновок експерта у цивільному судочинстві. Теорія $i$ практика інтелектуальноӥ власності. 2018. №2. С. 16-28

9. Про судову експертизу. Закон України № 4038-XII від 25.02.1994. Дата оновлен- ня: 01.01.2021. URL: https://zakon.rada.gov. ua/laws/show/4038-12\#Tехt (дата звернення: 03.12.2021).

10. Коротка Н. О. Цивільно-правовий статус експерта з питань права та його висновок у галузі права як засіб доказування у цивільному процесі. Науковий вісник Ужгородсъкого національного університету. Серія: Право. 2018. Випуск 53. Том 1. С. 97-100

11. Озерський I. В. Експертиза в галузі права як нова форма застосування спеціальних знань юридичного психолога. Юридичний науковий електронний журнал. 2019. №5. C. $313-316$

12. Старченко О. Проблемні питання процесуального статусу експерта 3 питань права. Підприємство, господарство і право : науково-практичний юридичний журнал. 2019. № 8. C. 26-29

13. Круковес В. В. Правовий статус експерта з питань права в цивільному судочинстві України. Актуальні проблеми правознавства. 2019. Вип. №2. с. 122-126.

14. Кармаза О., Кушерець Д. Експерт 3 питань права в судовому процесі: новели законодавства України. Підприємство, господарство і право. 2017. № 10. С. 32-36

15. Рішення Жовтневого районного суду м. Дніпропетровська від 01.04.2021 в справі № 201/11390/17. URL: https://reyestr.court. gov.ua/Review/96169291 (дата звернення: 03.12.2021).

16. Рішення Окружного адміністративного суду м.Києва в Рішенні від 15.03.2019 в справі №826/14930/18. URL: https://reyestr. court.gov.ua/Review/80534786 (дата звернення: 03.12.2021).

17. Рішення Сєвєродонецького міського суду Ауганської області від 25.07.2018 в справі №428/5142/18. URL: https://reyestr. court.gov.ua/Review/75489784 (дата звернення: 03.12.2021).

18. Постанова Верховного Суду від 30.10.2018 у справі №826/6667/16. URL: https://reyestr.court.gov.ua/Review/77508548 (дата звернення: 03.12.2021).

19. Шумило М. Експерт з питань права: новела процесуальних кодексів, що потребує обгранкування судовою практикою. Судово-юридична газета. 2019. URL: https:/sud.ua/ru/news/blog/133600-ekspert-z- 


\section{Цивільне, підприсмницьке, господарське та трудове право}

pitan-prava-novela-protsesualnikh-kodeksivscho-potrebuye-ogranki-sudovoyu-praktikoyu (дата звернення: 03.12.2021).

20. Щербаковськиий М. Г. Фахівець з питань права: експерт чи консультант?. Aкmyальні проблеми криміналістики та судової експертології : матеріали міжвідом. наук.-практ. конф. (м. Київ, 22 листоп. 2018 р.). Київ, 2018. C. $479-482$.

\section{REFERENCES}

1. Filipiev A. O. Problemy otrymannia advokatom informatsii pro zmist norm inozemnoho prava pid chas predstavnytstva interesiv kliienta v tsyvilnomu sudochynstvi. Chasopys Natsionalnoho universytetu «Ostrozka akademiia». Seriia «Pravo». 2010. Vyp. №1. s.1-8.

2. Antoniuk S., Zaiats O., Skrynkovskyi R. ta in. Problemy otrymannia advokatom pravovoi informatsii pro zmist norm inozemnoho prava pid chas predstavnytstva interesiv kliienta u tsyvilnomu sudochynstvi Ukrainy. Traektoriâ Nauki = Path of Science. 2019. Vol. 5.No 10, s.5001-5010.

3. Pro mizhnarodne pryvatne pravo. Zakon Ukrainy № 2709-IV vid 23.06.2005. Data onovlennia: 06.10.2021. URL: https://zakon. rada.gov.ua/laws/show/2709-15 (data zvernennia: 03.12.2021).

4. «The 7 Habits of Highly Effective People» by Stephen R. Covey, Free Press, New York, 2004

5. Pohoretska N. V. Vstanovlennia zmistu norm inozemnoho prava. Visnyk Kyivskoho natsionalnoho universytetu imeni Tarasa Shevchenka. Yurydychni nauky. 2012. Vyp.№ 93, s. 107-111

6. Tsyvilnyi protsesualnyi kodeks Ukrainy vid 18.03.2004 № 1618-IV . Data onovlennia: 05.08.2021. URL: https://zakon.rada. gov.ua/laws/show/1618-15 (data zvernennia: 03.12.2021).

7. Butyrska I.A. Pravovyi status eksperta z pytan prava u hospodarskomu protsesi. Naukovyi visnyk Uzhhorodskoho natsionalnoho universytetu. 2018. Seriia Pravo. Vypusk 48. Tom 1. S. 108-111.

8. Shtefan A. Vysnovok eksperta u tsyvilnomu sudochynstvi. Teoriia i praktyka intelektualnoi vlasnosti. 2018. №2. S. 16-28

9. Pro sudovu ekspertyzu. Zakon Ukrainy № 4038-XII vid 25.02.1994. Data onovlen- nia: 01.01.2021. URL: https://zakon.rada.gov. ua/laws/show/4038-12\#Text (data zvernennia: 03.12.2021).

10. Korotka N. O. Tsyvilno-pravovyi status eksperta z pytan prava ta yoho vysnovok $\mathrm{u}$ haluzi prava yak zasib dokazuvannia u tsyvilnomu protsesi. Naukovyi visnyk Uzhhorodskoho natsionalnoho universytetu. Seriia: Pravo. 2018. Vypusk 53. Tom 1. S. 97-100

11. Ozerskyi I. V. Ekspertyza v haluzi prava yak nova forma zastosuvannia spetsialnykh znan yurydychnoho psykholoha. Yurydychnyi naukovyi elektronnyi zhurnal. 2019. №5.S. 313-316

12. Starchenko O. Problemni pytannia protsesualnoho statusu eksperta z pytan prava. Pidpryiemstvo, hospodarstvo i pravo : naukovo-praktychnyi yurydychnyi zhurnal. 2019.№ 8. S. 26-29

13. Krukoves V. V. Pravovyi status eksperta $\mathrm{z}$ pytan prava $\mathrm{v}$ tsyvilnomu sudochynstvi Ukrainy. Aktualni problemy pravoznavstva. 2019. Vyp. №2. s. 122-126.

14. Karmaza O., Kusherets D. Ekspert z pytan prava v sudovomu protsesi: novely zakonodavstva Ukrainy. Pidpryiemstvo, hospodarstvo i pravo. 2017. № 10. S. 32-36

15. Rishennia Zhovtnevoho raionnoho sudu m. Dnipropetrovska vid 01.04.2021 v spravi № 201/11390/17. URL: https://reyestr. court.gov.ua/Review/96169291 (data zvernennia: 03.12.2021).

16. Rishennia Okruzhnoho administratyvnoho sudu m.Kyieva v Rishenni vid 15.03.2019 v spravi №826/14930/18. URL: https://reyestr.court.gov.ua/Review/80534786 (data zvernennia: 03.12.2021).

17. Rishennia Sievierodonetskoho miskoho sudu Luhanskoi oblasti vid 25.07.2018 v spravi №428/5142/18. URL: https://reyestr. court.gov.ua/Review/75489784 (data zvernennia: 03.12.2021).

18. Postanova Verkhovnoho Sudu vid 30.10 .2018 u spravi №826/6667/16. URL: https://reyestr.court.gov.ua/Review/77508548 (data zvernennia: 03.12.2021).

19. Shumylo M. Ekspert z pytan prava: novela protsesualnykh kodeksiv, shcho potrebuie obhrankuvannia sudovoiu praktykoiu. Sudovo-yurydychna hazeta. 2019. URL: https:// sud.ua/ru/news/blog/133600-ekspert-z-pitan- 
prava-novela-protsesualnikh-kodeksiv-schopotrebuye-ogranki-sudovoyu-praktikoyu (data zvernennia: 03.12.2021).

20. Shcherbakovskyyi M. H. Fakhivets $z$ pytan prava: ekspert chy konsultant?. Aktualni problemy kryminalistyky ta sudovoi ekspertolohii : materialy mizhvidom. nauk.-prakt. konf. (m. Kyiv, 22 lystop. 2018 r.). Kyiv, 2018. S. 479-482.

\section{Shchehlakov Ivan \\ 5 th year student of International law faculty of Yaroslav Mudryi National Law University shived1@ukr.net \\ REPORT OF THE EXPERT ON \\ LAW AS A SOURGE OF OBTAINING INFORMATION ABOUT THE CONTENT OF FOREIGN LAW BY AN ATTORNEY}

$A$ report of the expert on law as one of the ways in which attorney receives information about the content of foreign law was analysed in the article. It was noted that although the participants in the case are not obliged to prove to the court the content of foreign law, the active position of the lawyer in this case contributes to the better protection of the rights and interests of his client and provides a better chance to get a positive decision.

The report of the expert on law is a novelty of civil procedural law, which, among other things, serves as a source of information on the content of foreign law. The article determined that the use of reports of the experts on law was widely used in German litigation and allowed the court to learn about foreign law.

The authors note that the legal regulation of the institution of "legal expertise" has a number of shortcomings. The opinions of scientists and judicial practice, showing that there are now such problems as the unresolved procedure for obtaining the report of an expert on law, the lack of clear criteria for an expert on law, the contradiction of the criteria that are put forward to the expert, the unresolved significance of the report of an expert on law in civil proceedings was analysed in article.

The authors propose amendments to the current legislation, which will determine that the report of an expert on law can be obtained by order of the participant of the case at research institutes, universities, other research institutions of any form of ownership. It is also proposed to use objective criteria (such as an index of citations, the presence of scientific titles, insignia and awards) to determine the "recognition" of an expert on law. Defining in the legislation a list of cases (incorrect conclusion, contradiction of conclusion and non-compliance of the expert with the criteria) in which the court has the right to disregard the report of the expert on law was proposed in article.

It was noted that the report of an expert on law can be an effective tool for clarifying information about foreign law only after relevant legislative changes.

Keywords: expertise, expert on law, foreign law, lawyer. 